\title{
直埋ケーブル線路における部分放電測定方法の検証
}

\author{
正員陳 敏 ${ }^{\dagger}$, 正員 浦野 幸治 ${ }^{\dagger}$,
}

正員 関口 洋逸 ${ }^{\dagger}$, 正員 米田 英彦 ${ }^{\dagger}$, 正員 神野 厚英 ${ }^{\dagger}$, 正員 福永 定夫 ${ }^{\dagger}$

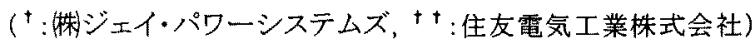

\section{Verification of Partial Discharge Measuring Method via Coaxial Bonding Wire} for Direct-buried Power Cable

Chen Min ${ }^{\dagger}$, Member; Koji Urano ${ }^{\dagger}{ }^{\dagger}$, Member; Yoitsu Sekiguchi ${ }^{\dagger}$, Member; Hidehiko Kometa ${ }^{\dagger}$, Member; Atsuhide Jinno ${ }^{\dagger}$, Member; Sadao Fukunaga ${ }^{\dagger}$, Member

$\left({ }^{\dagger}:\right.$ J-Power Systems Corp. $;^{\dagger+}{ }^{\dagger}$ : Sumitomo Electric Industries, Ltd.)

\begin{abstract}
This paper describes a new method of measuring partial discharge (PD) via coaxial bonding wire for direct-buried power cable, with which partial discharge can be measured at the so-called link box usually installed beside the joint but on the ground. When cable joints are directly buried under ground, it is difficult to use the conventional measuring method to detect PD, since it is necessary to install a PD detection sensor directly at or on the joint. For direct-buried cable line, the formation of sheath bonding for each joint can be usually determined at a link box that is connected to joint via coaxial bonding wire. Five kinds of PD sensing circuits were proposed for PD measurement at link box and the methods have been verified through several experiments using sample cables in laboratory or being carried practically on a real cable line on-site. The paper summarizes the experimental results and gives a comparison of each method. The paper also shows the possibility of measuring PD for three phases instantaneously at one joint bay on-site. Some practical PD measurement for those kinds of direct-buried power cable conducted onsite will be also introduced with on-site photos.
\end{abstract}

キーワード:部分放電，直埋ターブル，同軸ボンド線，クロスボンド結線，ブロッキングコイル，高周波 CT, 伝搬堿衰

Keyword: PD, buried cable, coaxial bonding wire, cross bonding, blocking coil, high frequency CT, propagation attenuation

\section{1. まえがき}

地中送電ケーブル接続部は現地で施工する必要があるた め，運用前に電気的性能を確認するための耐圧試験などが 実施されており，最近では超高圧 CV ケーブル線路をはじ めとする重要線路において部分放電 (P D ) 試験が実施さ れている。日本国内の超高圧地中送電線路は，主に洞道内 に布設されているため，接続箱へのセンサ取り付けが容易 であることから，様々な測定方法 (1)が提案されてきたが， 特に䇴電極センサを用いた方法 ${ }^{(2)}$ が一般に広く用いられ ている。PD検出感度についての要求は年々瑗しくなって きているが，この䇴電極法は，測定対象である接続箱に直 接センサを取り付けることで，高感度を実現している。

一方，海外の超高圧ケーブルの多くは，直埋式，すなわ ち地中に直接埋設する方式で布設されている。直埋線路に おいても，䇋工試験として高感度なP D 測定の奏施が強く 求められているが，䇴電極法などを適用してP D 測定を行 うためには，布設時に前もってセンサを取り付けておく必 要がある。すでに埋設された接続箱をも対象とした場合， 直接センサを取り付けることができないため，䇴電極法な どの従来法の適用は非常に困難である。このため, 直埋線
路での P D 測定は実施が困難であり，実施例もほとんど報 告されていないのが現状である。

そこで，著者らは前報 (3)にて直埋状態にある接続箱の PDを測定する方法を提案した。これは，測定のための特 別な線路工事なしにPD試験を行うことができ，端工試験 や定期点検等の合理化を図ることが可能である。本論文は， 直埋線路でのP D測定方法について前報よりもさらに詳細 な検討を行ったものであり，現地でのP D 測定実施に適し た具体的な測定方法を提案した。またこれに基ついて，塞 際に直埋状態での実線路においてPD測定を行った結果を 報告する。

\section{2. 直埋ケーブル線路のPD検出方法}

日本国内の超高圧地中送電線路では, 竣工耐圧試験など でPD測定が行われており，線路の高電圧化に伴って検出 感度についての要求が年々厳しいものとなっている。国内 の電力ケーブルは主に洞道内に布設されているため, 測定 対象である接続箱に直接センサを取り付けることで，高感 度でのP D 測定を実現している。近年, 海外の直埋線路に おいても健全性を確認するための高感度な P D 測定の害施 が強く求められているが，直埋線路で部分放電を測定しよ 
うとしても，すでに埋設された接続箱に直接センサを取り 付けることができないため，測定が非常に困難であった。 結線方法の変更やアレスタを取り付けるなどの目的で, 直埋ケーブルの接続部シースは，図 1 (a)に示すように同 軸ケーブルによって地上に設置されたリンクボックスまで 導かれることが多い。この同軸ケーブルはシース電流を流 すことを目的としており, 特に超高圧線路では導体サイズ が $300 \mathrm{~mm}^{2}$ 以上で長さ $10 \sim 30 \mathrm{~m}$ 程度のものが使用されて いる。リンクボックスの端子は，図 1 (b)，（c）の様に金 属板で IJ 結線（三相のシースをクロスボンドする）や NJ 結線（同じ相のシースを短絡）に接続される。

そこで, 著者らはこの直埋線路での P D 測定法について 検討を行い, リンクボックスにセンサを取り付けて P D 測 定を行う同軸ケーブル法を前報 (3)にて提案した。前報の 同軸ケーブル法は, リンクボックスの接続端子にコイルを 取り付けることで, P Dによってシースに発生する高周波 信号を同軸ケーブルを介して検出するものであり，比較的 容易に実施することができる。前報における回路解析と実 験検証によって，同軸ケーブルのインピーダンスによって 若干感度が低下するものの, 原理的に測定が可能であるこ とを明らかにした。

しかしながら, 前報で示した方法は NJ 結線のリンクボ ックスには容易に適用することが可能であったが，測定対 象が IJ 結線の場合は線路の接地系統を変更することにな ってしまう。実線路への適用を考慮すると，接地系統を変 更せずに IJ 結線のままで P D を測定する結線方法が必要 であると考えられる。そこで，前報で示した方法以外の結 線方法を提案し, 検証実験と現地測定適用一の検討を行っ た。

\section{3. 検出法の検証実験}

3. 1. 近接注入による検証実験 提案する各結線方法に おいて, 同軸ケーブルによる感度低下について検討を行う ため, 図 2 に示す模擬実験回路を構築し, ケーブルコア ーシース間に信号を直接注入（近接注入）した時の検出信 号について実験を行った。シース中央に電気的非接触とし た絶縁部を設けて接続箱を模擬した超高圧 C V ケーブルに, 実線路で使用されている同軸ケーブルを接続し，リンクボ ックスを模擬した。ここで，現地では三相同時測定が必要 なため, 3つの模擬接続箱を用いた。その同軸ケーブル先 端に, 表 1 に示す 5 つの結線方法でセンサを取り付けた。 (1)，(2)は NJ 結線での接続方法，(3)～(5)は IJ 結線での接続 方法である。ここで，(1)は前報で示した従来法であるが，

三相結線時の他相への影響を確認するため, また他結線方 法との比較のために実施した。また，スペクトラムアナラ イザでの周波数分布測定の結果から，低周波ノイズと同軸 ケーブルの減衰を考慮し，測定周波数を $10 \sim 30 \mathrm{MHz}$ とし た。

注入点 1 のケーブルコアーシース間ヘパルスジェネレー タ（PG）によってP D模擬パルスを注入し，センサ $\mathrm{S} 1$ 〜

電学論 $B, 122$ 巻 4 号, 平成 14 年

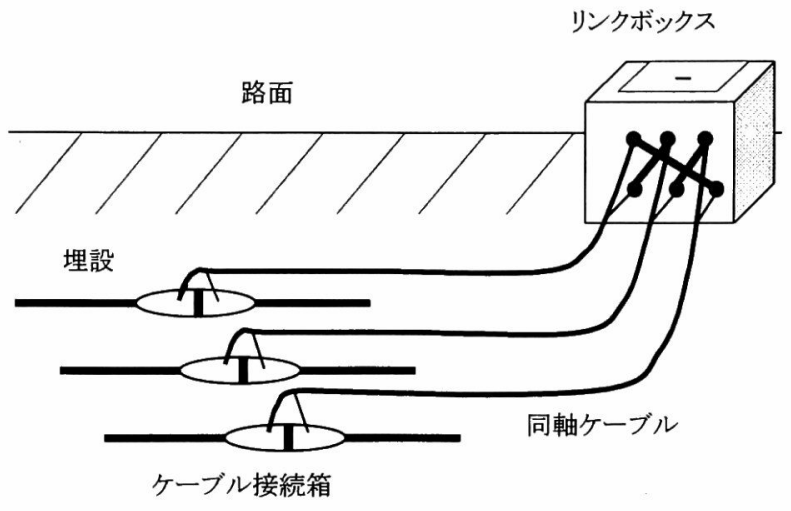

(a) 直埋式線路のリンクボックスの概要

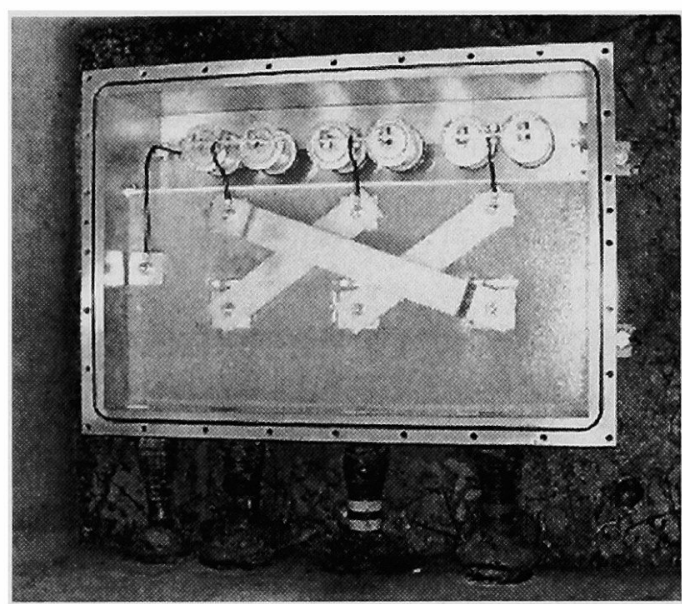

(b) リンクボックスの IJ 結線

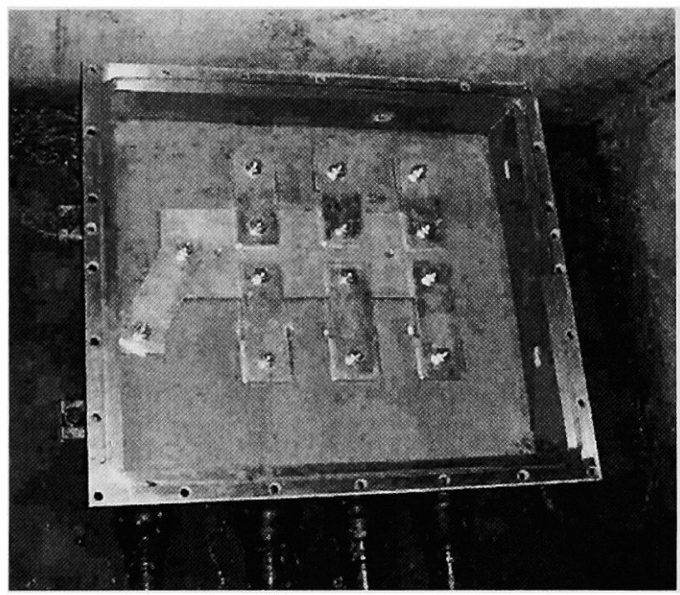

（c）リンクボックスの NJ 結線

図1 直埋式線路のリンクボックス

Fig.1. Link Box for Direct-Buried Cable

S4 で信号を観測した。これを表 1 に併記するが，検出方 法の違いによらず，同軸ケーブル法（S4）の信号レベル は箔電極法（S2）のおよそ 1/2〜1/3 であった。表中には 示していないが，注入点 2 よりパルスを注入した場合では， S4 : S2 の関係はちょうど逆となる。この結果は前報とほ ぼ一致しており，S4：S2 の割合を把握することで, ここ 


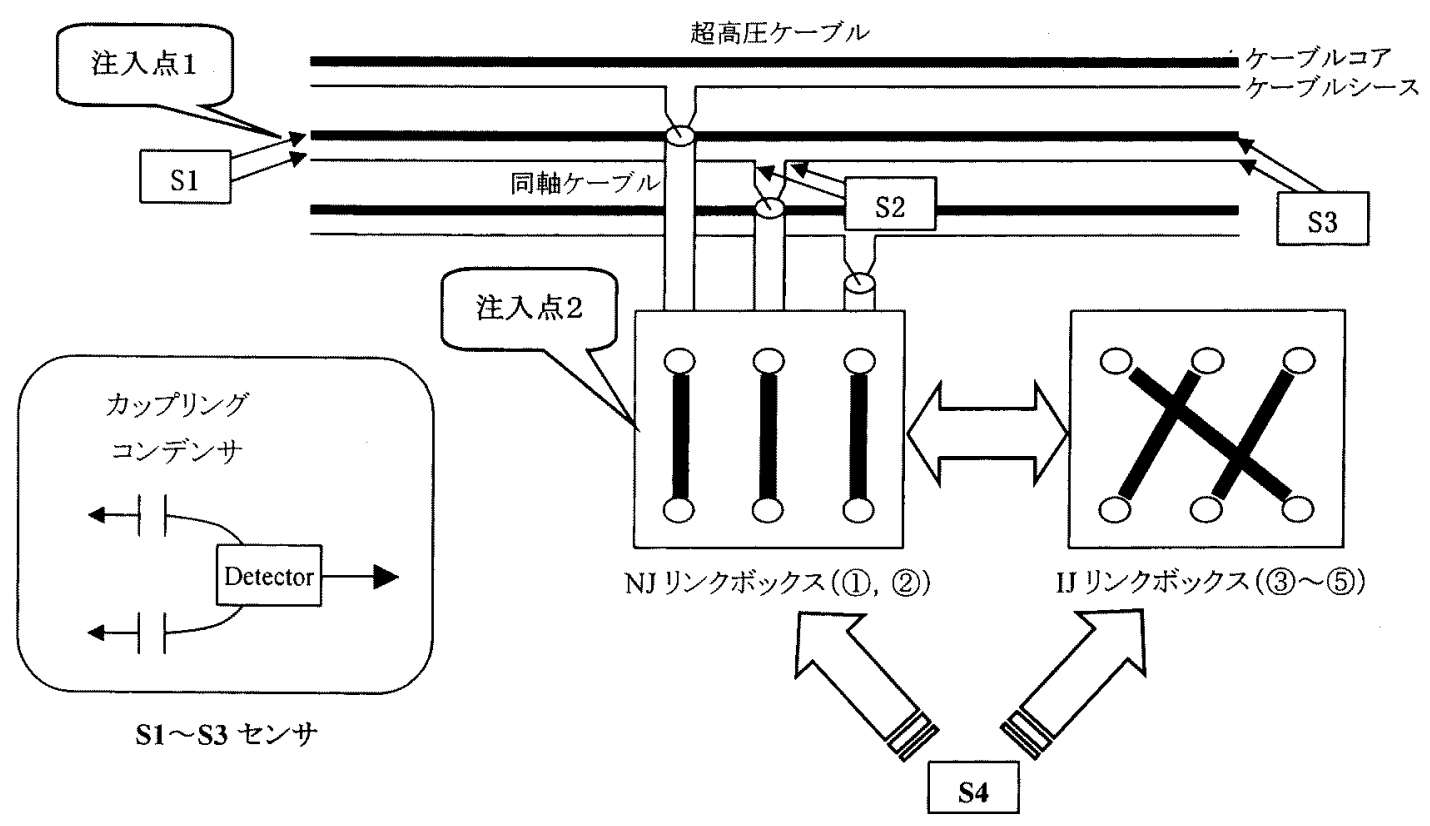

図2 近接注入用模擬実験回路

Fig.2. Experiment Circuit with Sample Cables for Local Injection

で提案した 5 種の結線方法全てで定量的な較正が可能であ ることを示している。

検出感度に着目すると, IJ 結線に比べ $\mathrm{NJ}$ 結線で感度が

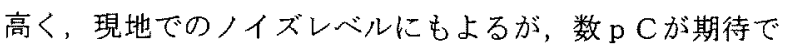
きる。また，IJ 結線，NJ 結線共に高周波ブロッキングコ イルを用いた方法で検出感度が高い。すなわち，詳細な測 定にはコイルを用いた方法(1)，(3)）が適しているといえる。

3. 2. 隣接注入による検証実験 同軸ケーブル法で信号 を正常に検出していること確認し，さらに異常相以外の 相人の影響を評価するため，図 3 に示す回路を構築して 実験を行った。超高压線路のリンクボックスに表 1 と同様 な結線方法でセンサを取り付け、ここから $500 \mathrm{~m}$ 離れたリ ンクボックスのA相に 250pC の模擬パルスを注入（隣接 注入）し信号を測定した。検出結果を表 2 に示すが，全 ての結線方法で信号を検出していることが確認できた。こ のことは，接続箱でPD信号が発生した場合でも，信号検
出が可能であることを裹付けるものである。

各結線方法における隣接注入時の検出感度は, 概ね $100 \mathrm{pC}$ 程度であり, $10 \mathrm{MHz}$ 以上の信号は減衰が大きい。 また、コイルを使用した方法(1), (3))では，異常相以外の 相への影響がほとんどみられず，異常相の特定が可能であ ることが示唆された。(4), (5)の手法では, 異常相以外の相 でも信号が検出されており，異常相の特定は困難である。

3. 3. 現地測定適用への検討これまで，5種の結線 方法について実験による検討を行ってきたが，ここでは作 業性や測定実施の容易さなどを含め，実際に現地測定に適 用するための検討を行った。

実験結果と作業性などを，表 3 にまとめて示す。検出感 度が高く, 異常信号を榆出した際に異常相の特定が容易な ことから，ブロッキングコイルを用いた結線方法(1), (3)) が，詳細な測定には最も適している。しかしながら、この 方法はコイルにシース電流を流す必要があり電流容量に対

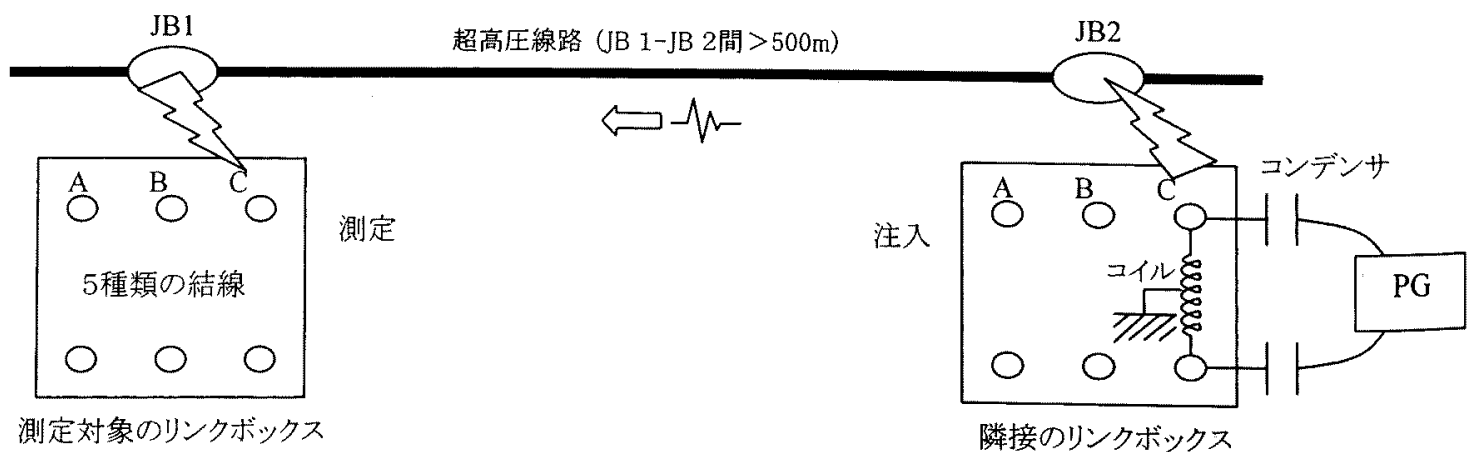

図3 400kV 線路での隣接注入実験

Fig.3. Next-joint Injection and Measuring Experiments at Real EHV Cable Line 


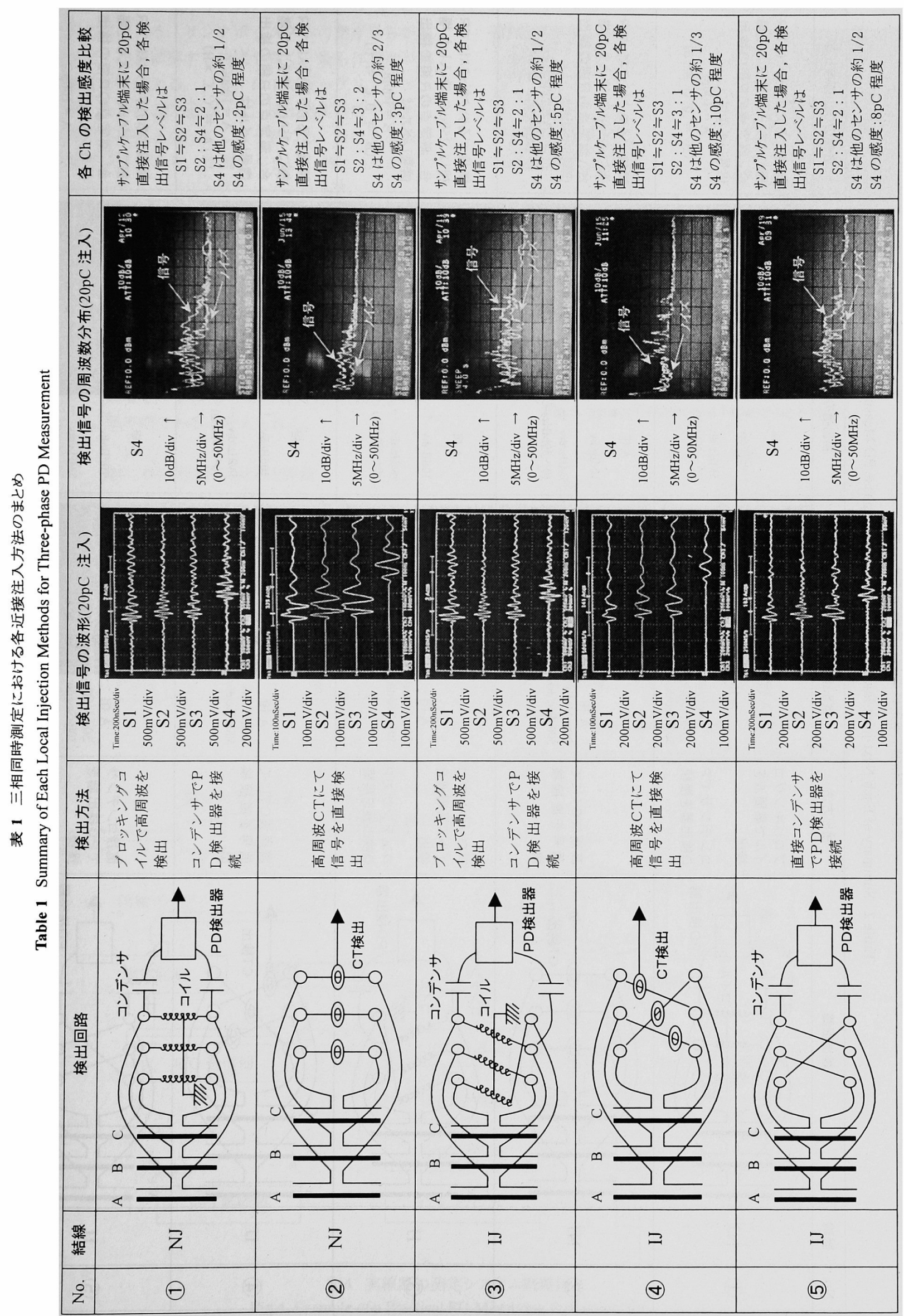




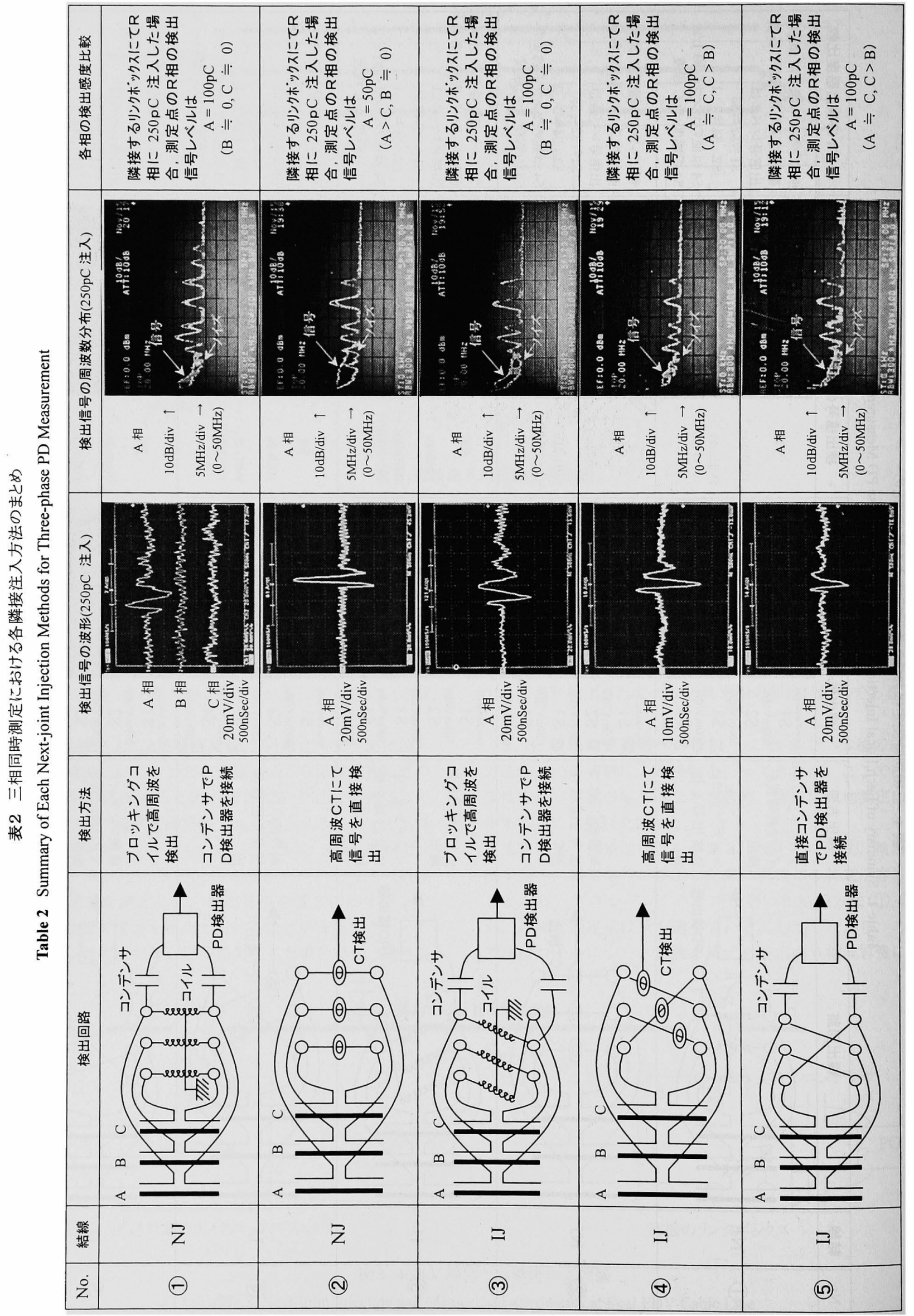


する検討が必要である, リンクボックスへの槃ぎ込みが面 倒であるなど, 作業に要する時間も長く, 最も作業性が悪 い方法であるともいえる。一方，CTやカップリングコン デンサを用いた方法 (2), (4), (5)) は, 検出感度が若干落ち, 異常相の特定が困難となってしまうものの, センサの繋ぎ 込みが非常に簡単であり，作業性が良い。特に IJ 結線の 場合, (5)の方法はカップリングコンデンサを介してリンク ボックスの端子にセンサを繫ぎ込むだけで斉むため, コイ ルを用いる方法に比べ作業性が非常に良い。

以上の検討結果より，詳細な測定が必要なケースでは， ブロッキングコイルを用いた方法の1), (3)が適していると いえる。しかしながら, 停電時間を短くするため, 実線路 での測定では検出感度が若干低下しても測定準備時間を短 縮すべき場合も多く，まず作業性の良い方法 (2), (5))にて 剆定を行い, 異常信号を検出した場合に詳細な測定 (1), (3) を行うのが効率的であると考えられる。

表3 各検出方法の比較と評価

Table 3 Comparison and Evaluation of Each Measuring Method

\begin{tabular}{|c|c|c|c|c|c|c|}
\hline $\begin{array}{c}\text { ケース } \\
\text { No. }\end{array}$ & $\begin{array}{c}\text { 結線 } \\
\text { 方式 }\end{array}$ & $\begin{array}{c}\text { 検出 } \\
\text { 方法 }\end{array}$ & $\begin{array}{c}\text { 検出 } \\
\text { 感度 }\end{array}$ & $\begin{array}{c}\text { 異状相 } \\
\text { 特定 }\end{array}$ & $\begin{array}{c}\text { 作業性 } \\
\text { の評価 }\end{array}$ & $\begin{array}{c}\text { 淮備に必 } \\
\text { 要な時間 }\end{array}$ \\
\hline (1) & $\mathrm{NJ}$ & コイル法 & $\bigcirc$ & $\bigcirc$ & $\times$ & かかる \\
\hline (2) & $\mathrm{NJ}$ & $\mathrm{CT}$ 法 & $\bigcirc$ & $\bigcirc$ & $\triangle$ & 短時間 \\
\hline (3) & $\mathrm{IJ}$ & コイル法 & $\bigcirc$ & $\triangle$ & $\times$ & かかる \\
\hline (4) & $\mathrm{IJ}$ & $\mathrm{CT}$ 法 & $\triangle$ & $\times$ & $\triangle$ & 短時間 \\
\hline (5) & $\mathrm{IJ}$ & コンデンサ法 & $\triangle$ & $\times$ & $\bigcirc$ & すぐできる \\
\hline
\end{tabular}
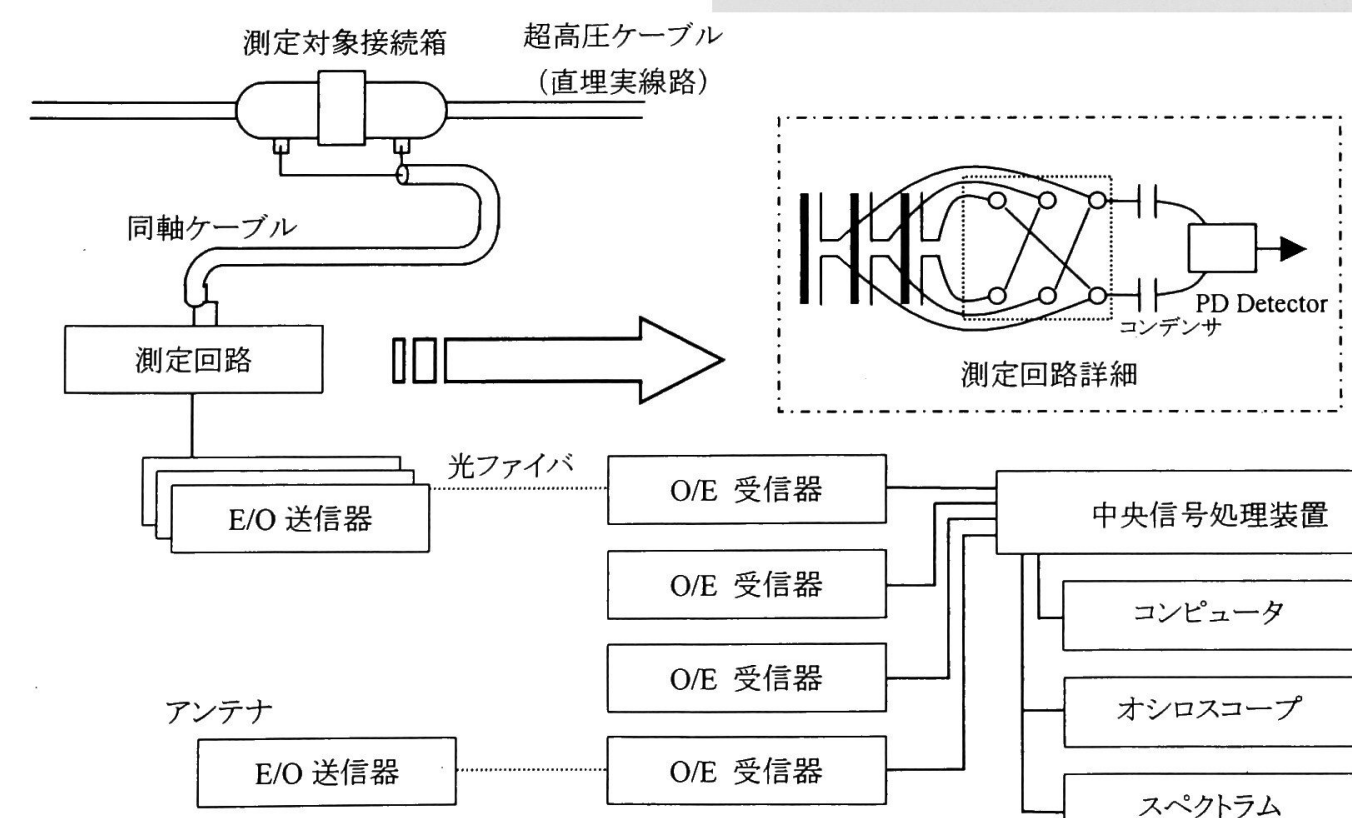

図5 センサ接続状況および測定の様子

Fig.5. Sensor Circuits and Measuring System

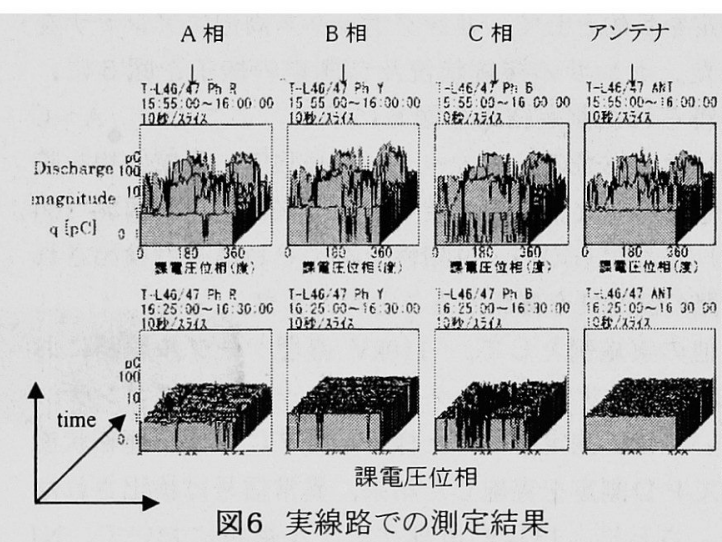

Fig.6. Example of a Practical Measurement Results

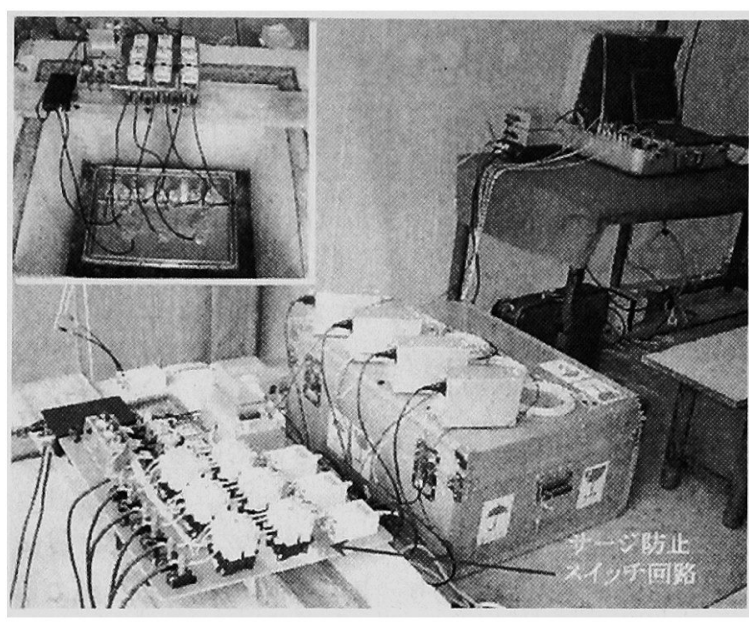




\section{4. 実線路での測定結果}

これまでに，直埋ケーブル線路における P D 測定方法に ついての検証試験と適用検討を行ってきた。この方法を用 いて，実際に海外の直埋ケーブル（超高圧実線路）におけ るP D 測定を行った。線路と測定システムの概要を図 4 に示す。測定対象の接続箱は, 約 $20 \mathrm{~m}$ の同軸ケーブルを 介してリンクボックスに接続されており，リンクボックス にて IJ 結線となっている。このケースでは，金属板によ ってリンクボックス端子が IJ 結線されているため，作業 性を考慮して(5)の結線方法で測定を行った。この方法は力 ップリングコンデンサを用いてリンクボックス端子に直接 センサを接続するものであり，異常信号が発生した際の相 特定は困難であるが，リンクボックスの配線を変更する必 要がなく作業性が非常に良い。実際に，作業時間を大幅に 短縮することができ，作業性が非常に向上した。また，， イズ測定を目的として，リンクボックス周辺にアンテナを 設置した。センサの接続状況及び測定の様子を図 5 に， 現地で得られた測定結果を図 6 に示す。ここでは, $\mathrm{A} \sim \mathrm{C}$ 相とアンテナ信号の $\mathrm{q}-\phi-\mathrm{t}$ （信号強度一課電位相一時 間）分布を示した。時折，突発的な外来ノイズが観測（図 中上段）されたものの，位相性を持つ P D信号は検出され ず，線路の健全性を確認することができた。

この他の実施例として, $110 \mathrm{kV}$ 直埋ケーブル線路にお ける IJ 結線のリンクボックスで, カップリングコンデン サを用いて PD 測定を行った様子を図 7 に示す。運転状態 においてPD測定を実施した結果，異常信号は検出されな かった。さらに, $132 \mathrm{kV}$ 直埋ケーブル線路において, NJ 結線のリンクボックスの各相に, 高周波 C Tを挿入して P $\mathrm{D}$ 測定を行った様子を図 8 に示す。(1)のブロッキングコ イルを使用した場合と比較すると，接続箱にセンサを慗ぎ 込む作業を短時閒に行うことができ，作業量を減少させる ことが可能となった。この例においても，線路の運転状態 において異常信号は検出されず, 線路の健全性を確認でき た。

\section{5. まとめ}

直埋ケーブル線路に設置されたリンクボックスの端子に センサを接続してP D 測定を行う同軸ケーブル法において， センサの結線方法を新たに提案した。これらの検出方法に ついて検証実験を行い, センサ結線方法による検出感度を 明らかとした。また，作業量や異常相の特定など，実線路 での測定時に有用であろう項目についても併せて検討し, 現地での測定に適した方法を提案した。以上の結果をもと に, このP D 検出方法を用いて国外の直埋式実線路のP D 測定を実施しここの測定例について示した。これらの測定 結果と較正結果から，本測定法の有用性と実用性を示した。

(平成 13 年 8 月 6 日受付, 平成 13 年 11 月 22 日再受付)

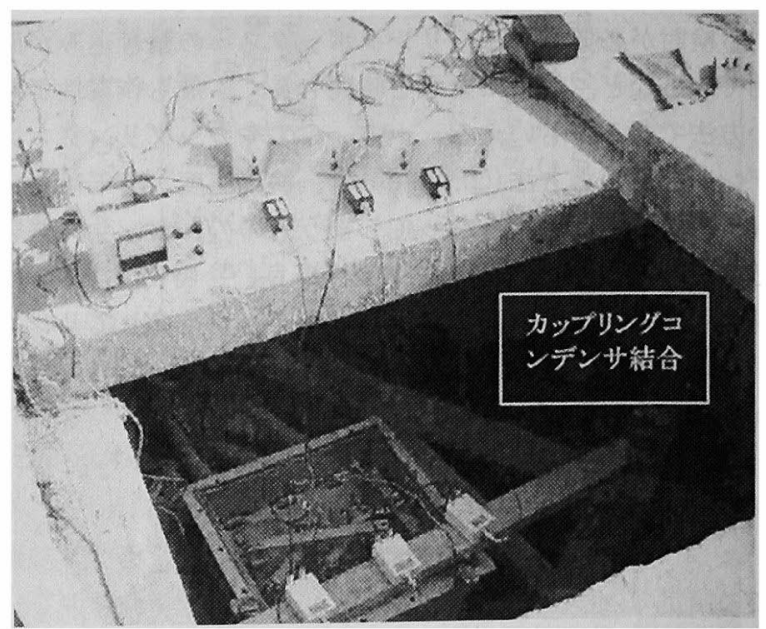

図 $7110 \mathrm{kV}$ 線路の測定様子

Fig. 7. PD Measuring System for $110 \mathrm{kV}$ Cable Line

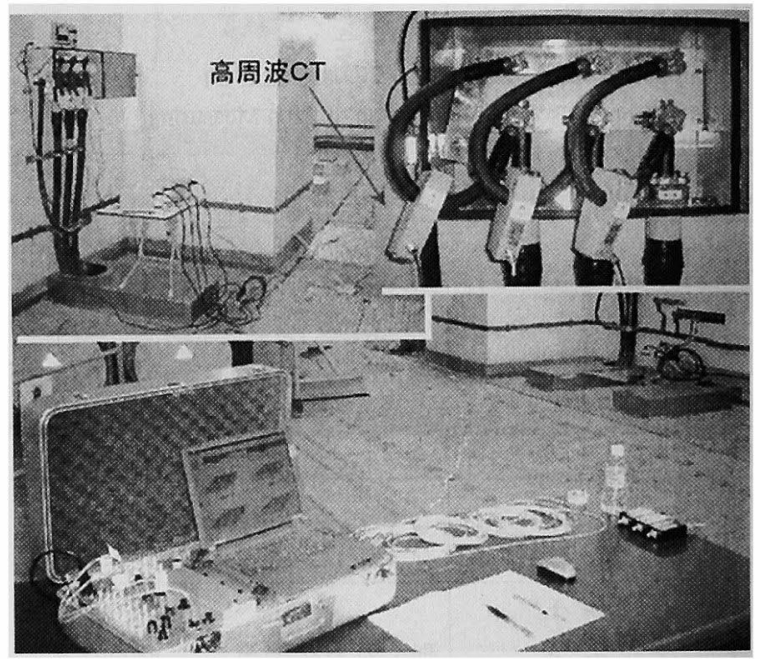

図8 $132 \mathrm{kV}$ 線路の測定様子

Fig. 8. PD Measuring System for $132 \mathrm{kV}$ Cable Line

文献

（1）電気学会技術報告第695号

（2）勝田銀造·戸谷 敦·遠藤 桓・鈴木弘・関井康雄:「超高 圧長尺CVケーブル線路の活線部分放電検出法の開発」, 電学論B, 111巻, 11 号, 1223〜1232(平3-11)

（3）陳他:「直埋ケーブル線路における部分放電測定方法の 検討」, 電学論B, Vol.121-B, No.1,pp.95-101 


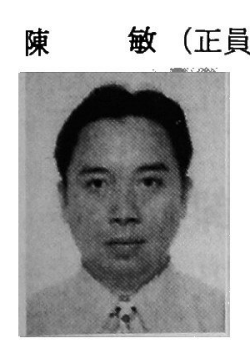

(正員) 1960 年 2 月 14 日生まれ。1992 年 3 月 東京工業大学大学院理工学研究科電気 電子工学専攻修士程修了。同年 4 月住 友電気工業 (株) 入社, 送電線系統EMT P解析と電カケーブルの診断技術に関す る研究に従事。現在、潄ジェイ・パワーシ ステムズ研究開発センター所属。

浦野幸治（正員） 1971 年 3 月 27 日生まれ。1998 年 3 月

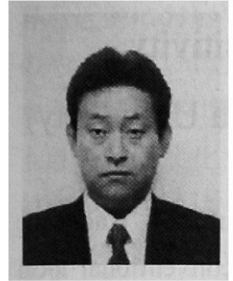
武藏工業大学大学院工学研究科電気工 学専攻博士課程修了。同年 4 月住友電 気工業(株) 入社。主として電カケーブル の診断技術に関する研究に従事。博士 (工学)。

関口 洋逸（正員） 1961 年 1 月 25 日生まれ。1986 年 3 月

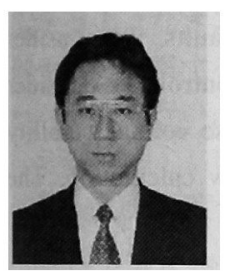
大阪大学大学院理学研究科博士前期課 程修了。同年 4 月住友電気工業(株)入 社。主として、電力ケーブルの研究開発に 従事。現在、㑣ジェイ・パワーシステムズ研 究開発センター所属。

米田 英彦（正員） 1960 年 6 月 8 日生まれ。1985 年 3 月

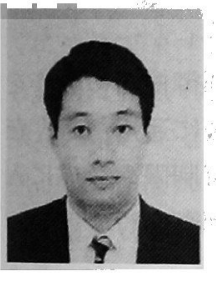
大阪大学大学院工学研究科応用物理学 専攻 (前期課程) 終了。同年 4 月住友電 気工業(株) 入社。架空送電線・電力ケ一 ブルの監視システム開発・納入に従事。 2001 年 10 月より, (株)ジェイ・パワーシス テムズ電力情報システム部所属。

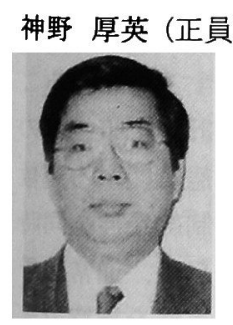

1952 年 1 月 29 日生まれ。1976 年 3 月 京都大学大学院工学研究科電気工学修 士課程修了。同年 4 月住友電気工業侏 入社。主に超高圧電力ケーブル・システム の開発，設計、製造に従事。現在、㑣ジェ イ・パワーシステムズ電力事業部技術部所 属。

福永定夫（正員） 1949 年 4 月 10 日生まれ。1974 年 3 月

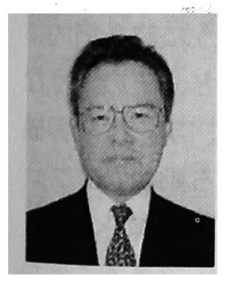
東京大学大学院工学系研究科修士課程 修了。同年 4 月住友電気工業(株) 入社。 電カケーブル関倸の業務に従事して 2001 年 6 月 同社取締役。2001 年 10 月 より(株)ジェイ・パワーシステムズ 取締 役。 